REFLECTIONS:

NEUROLOGY AND

THE HUMANITIES

Section Editor

Anne W. McCammon,

MD, FAAN

\title{
The Man Who Played Pinochle With Dogs
}

J. Thomas Hutton, MD, $\mathrm{PhD}, \mathrm{FAAN}$

Correspondence \& reprint requests to Dr. Hutton: jthomas_hutton@yahoo.com
I strode toward a full chart rack. The intake note read: "75-year-old Muleshoe farmer, eight-year history of PD, med check."

Wasn't Muleshoe that cotton town northwest of Lubbock near the infamous Bloated Goat Saloon? I had heard about this boot-scooting, brawl-provoking West Texas watering hole.

I scanned prior chart notes, planned my examination, and considered treatment options. Like battle plans in war, my considerations would soon become obsolete.

As I entered, an elderly man sitting on the exam table glared. He was short and had a face as fissured as a prune.

"What's keeping you, doc, playing golf?"

"Sorry to keep you, Mr. Woodley. I'm Doctor Hutton. What can I do for you today?"

The man peered at me like a hawk sizing up its prey. He wore a sweatshirt that screamed, "If things get better with age, then I'm approaching MAGNIFICENCE." I sat on the exam stool and acted nonchalant, as if I had ample time to wait out his petulance.

"It's nice to finally see you," he intoned, not yet abandoning his pique. While his words were barbed, his west Texas drawl and soft Parkinson's speech reduced their sting.

"Mr. Woodley, I see Doctor Reynolds treated you." Doctor Reynolds, the founder of the Parkinson's Clinic, had since decamped for a position at Johns Hopkins.

The corners of Sam Woodley's mouth turned up slightly. He nodded his head and ran a gnarled hand along the exam table, smoothing the paper.

"Yep, for years Doc Reynolds was my doctor. Without him, suspect I'd move slower'n a constipated slug. Liked that funny talking Yankee." I continued my get-acquainted conversation, sensing a thaw in my frigid reception.

"Do you have family?"

"Wife up and died 3 years ago. Kid took off for godless California. Not much to do since leasing out the farm."
After a few sympathetic clucks, I asked, "Live by yourself?"

"Yep, but ya see a young heifer wantin' to play house with an old fart like me, ya let me know!" A mischievous grin came over his weather-beaten face.

I began to admire the pluck of this old farmer. "I'll keep it in mind, Mr. Woodley. How do you spend your time?"

"Frankly, not much. Just call me Sam."

"Okay, Sam, what do you do with your time?"

"Take care of the homestead. Played cards with my Gladys, before cancer took her." Before he turned his head away, I noticed his eyes begin to glisten. His defiance by then had dissipated, replaced by vulnerability and loneliness.

I steered the conversation toward his health. "How's your Parkinson's been treating you, Sam?"

Sam began describing difficulty cutting his food and tying his shoelaces. His tremor and shuffling feet embarrassed him. Surprisingly, he said he also found it harder to shuffle cards. Why, I wondered, did he need to shuffle cards?

Sam conceded his memory had slipped. I listened, nodded, sympathized, and discussed making lists. I inquired about side effects of his medicine with a series of nonproductive questions. Then I asked, "Have you seen animals or people that were not really there?”

Sam hesitated. I noticed his jaw muscles tighten. His face took on a look of puzzlement that could not have been greater if I had stood on my head and begun to spit marbles. Sam measured me, his bushy eyebrows knitting up like 2 angry caterpillars about to do battle.

"Maybe, maybe not."

"Please tell me more."

He ran the back of his hand across his square chin. I observed his lips quiver. After taking an unusual interest in the ceiling tiles, Sam Woodley finally blurted, "Well, doc, I see dawgs."

I quickly followed up in my best nonjudgmental tone. "Dogs, huh? Well, big or little?"

Sam tugged at a dangling earlobe. With a weary sigh, his resistance gave way. He shared his mystery 
by relating a bizarre story. Trust must be earned, as it resides at the core of the doctor/patient relationship. Sam provided his guarded experiences that allowed me insight but also created for me a challenging dilemma.

"Well, 'bout every afternoon 3 dawgs drop by." He fell silent awaiting my response to this snippet.

"Go on," I gently urged.

In his monotone he described a large yellow Labrador, a black and white Border Collie, and a smaller white and brown Cocker Spaniel.

"Are they scary?" I asked.

"Nah, gentle as can be. Besides, we play together."

Puzzled where the conversation was leading, I asked if the dogs had names.

He nodded. "Yellow Dawg's the Lab, Skipper's the collie, and Coco's the spaniel."

"Well, what do they do?"

"Mostly like to play cards."

I wondered if my ears were tricking me. "Oh, I see," I said, trying to sound as if I was often told about 3 dogs playing cards. "Well, what card games do y'all play?"

"Usually pinochle, their favorite."

"So, play pinochle, do they?"

"Oh yeah, especially Skipper and Coco."

"I see. Make noise while they play?"

"Never a sound, but I know what they want."

"Please tell me how you and the dogs go about playing pinochle."

Sam described how he would place the card table and arrange the dogs' chairs. He would then invite the dogs onto their chairs and begin the game. "Coco likes to beat the boys. Upsets her if she loses. Been known to leave in a huff."

He described shuffling and dealing but admitted he had been having difficulty managing the cards. Sam said his canine friends had even greater difficulty than he did, forcing Sam to deal.

"You see, doc, my hands aren't as good as before this here Mr. Parkinson's disease. Be obliged if you'd just, well, give it back to him!" With his quip, an endearing smile crossed his weathered, old face.

"Well, maybe I can help," I encouraged. Intrigued by his narrative, I gestured for him to continue.

"Well, Skipper, the Border, wears green eyeshades, you know, like bookkeeper types, and uh, Coco, the Cocker Spaniel, sits on a pink handkerchief. Thinks it makes her lucky. Oh, and Coco sits with the floorboards, not across them-feels strong bout this, just like my Gladys. Suspect Yellow Dawg comes for the sandwiches. He's not good at pinochle."

My mind was reeling, visualizing this elaborate scene. I concentrated, trying not to project incredu- lity. Sam was relating an unreal event with the nonchalance of describing weather changes or the cotton crop. Was his elaborate hallucination prompted by Cassius Marcellus Coolidge's series of pictures, Dogs Playing Poker? My knowledge of pinochle was not extensive, but I knew it was a game for 2 to 4 people, not a pastime for dogs.

Mentally I had already determined that Sam required a medicine change to get rid of his hallucinations.

With twinkling brown eyes, Sam warmed to his narrative. I observed his hand tremor increase, as he affectionately described his daily visitation.

"I make sandwiches before they come. Yellow Dawg likes ham and cheese and lots of "em. The spaniel and collie prefer turkey."

He told of putting out dog biscuits. "They prefer beef flavored ones." I sensed Sam's pride as host. "Put down a bowl of water in case they're thirsty."

"Mr. Woodley, can you touch the dogs?"

"Nah, if I try, hand passes right through "em. Makes 'em disappear. Learned not to."

"What about smelling the dogs?"

"Hadn't thought 'bout it, but can't smell 'em, feel 'em, or hear 'em neither." I considered for a few moments what I had heard. Sam's hallucinations fit with medication-related side effects of PD but they sounded more complex than I had previously encountered.

"When we finish the game, dawgs head for the door. Disappear without me even opening it."

"Do you and the dogs play anything beside cards?" I wished to learn the extent of his interaction with the dogs and whether an emotional dependence on them existed.

Sam thought and then replied, "Watch the Cowboys on TV. Don't know about being America's team, but sure as hell the dawgs' favorite." Sam laughed heartily. His hand tremor again increased, acting like his emotional barometer.

"How do you know that?"

"Well, Cowboys make 'em a touchdown, Skipper jumps off the couch and tears around the room, jumping over furniture- his own little end zone celebration. If the other team scores, dawgs lay their chins on their paws and look real sad. Easy to read my dawgs."

I was by then more certain his hallucinations needed squelching.

“Mr. Woodley, a healthy person's ability to move about is like a wagon pulled by a team of 8 horses. With Parkinson's only 2 healthy horses remain to haul the wagon. To keep it moving, we drive these 2 harder with medicines, like swinging a whip over the horses' heads." 
Sam sat quietly, listening to my analogy, one to which I hoped he could relate.

"Unfortunately, urging them too hard can cause horses to get balky, like side effects, such as seeing things not really there." Sam listened without comment. I explained how Parkinson's had diminished his store of dopamine and that levodopa/carbidopa supplemented his brain's inadequate supply.

"You see, Mr. Woodley, too much treatment causes hallucinations. We must reduce your medicine."

Sam sat motionless. Then his mouth began chewing movements, as if chewing his thoughts into declarative sentences. He then crossed his arms across his chest. I quickly assured him that we could banish his hallucinatory hounds.

He at last replied, "Don't know 'bout that, doc."

I was taken aback. "Well, you agree we need to get rid of your hallucinations?"

"Dawgs ain't bothering me none."

I considered what further arguments to make. "Are you worried about your movements slowing?"

"Nah, I got plenty of time to do my work." Sam chewed more before asking, "But how would I spend my afternoons, if I didn't play pinochle with my friends?"

I searched for a rejoinder, but before finding one, Sam Woodley added, "Besides, whatever would I do with all the extra sandwiches?”

Such rarified moments provide insight. I gained a better understanding of the unmet emotional needs of Sam Woodley. The experience also reminded me to view the situation through the other person's eyes, a valuable lesson in medicine and in life.

My earlier training had taught me that hallucinations required adjustment of medicine. I knew hallucinations could be well tolerated, and rarely welcomed. But I also understood hallucinations could increase and become frightening.

Sam showed no signs of hostility or incipient paranoia and claimed reduced boredom. But still these hallucinations were florid. And what would my new colleagues think if I failed to address them?

Hours later, after completing my charting and shrinking a stack of paperwork, I directed fatigued footsteps toward the doctors' lot.

My thoughts returned to Sam Woodley. I hoped he had arrived home safely. Remembering his pugnacious approach to life made me smile.

Had his combativeness arisen from a lifetime of farming cotton in borderline soil, violent weather, and semiarid conditions? Sam's sad lack of human connectedness struck me as bleak as the flat, treeless Llano Estacado, his loneliness, disease, and his medicine having given rise to his illusory dogs. Multiple factors contributed to his elaborate phantasm. One thing seemed certain; his dogs had provided unusual companionship. I felt satisfaction, knowing I had gained sufficient trust for him to share his dogs with me. Thirty years later, I appreciate his trust no less.

I visualized Sam arriving at his remote farmhouse. I imagined him placing the table parallel to the floorboards and moving the dogs' favorite chairs. Perhaps he fixed enough ham and turkey sandwiches to satisfy the hungry Labrador. I felt a smile cross my face. I felt confident about my decision, considering this individualistic man and his lifestyle.

For now, Sam Woodley would continue to enjoy his extraordinary pinochle parties with his dawgs. 


\title{
Neurology
}

\author{
The Man Who Played Pinochle With Dogs \\ J. Thomas Hutton \\ Neurology 2012;79;e143-e145 \\ DOI 10.1212/WNL.0b013e318270407c
}

This information is current as of October 22, 2012

\section{Updated Information \& Services}

Subspecialty Collections

Permissions \& Licensing

Reprints including high resolution figures, can be found at: http://n.neurology.org/content/79/17/e143.full

This article, along with others on similar topics, appears in the following collection(s):

\section{Hallucinations}

http://n.neurology.org/cgi/collection/hallucinations

Parkinson's disease/Parkinsonism

http://n.neurology.org/cgi/collection/parkinsons_disease_parkinsonism Professional conduct and ethics

http://n.neurology.org/cgi/collection/professional_conduct_and_ethics Quality of life

http://n.neurology.org/cgi/collection/quality_of_life

Information about reproducing this article in parts (figures,tables) or in its entirety can be found online at:

http://www.neurology.org/about/about_the_journal\#permissions

Information about ordering reprints can be found online:

http://n.neurology.org/subscribers/advertise

Neurology ${ }^{\circledR}$ is the official journal of the American Academy of Neurology. Published continuously since 1951, it is now a weekly with 48 issues per year. Copyright Copyright (? 2012 by AAN Enterprises, Inc.. All rights reserved. Print ISSN: 0028-3878. Online ISSN: 1526-632X.

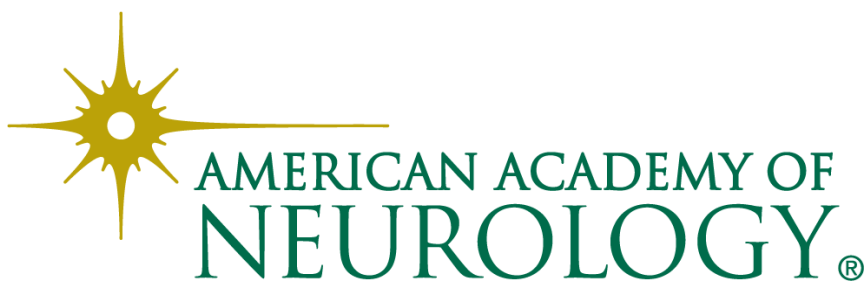

